\title{
Experimentally Tested Theory: A Scientific Means For Inferring Social Structure
}

\author{
Pamela Emanuelson ${ }^{1 *}$, David Willer ${ }^{2 *}$ \\ ${ }^{1}$ North Dakota State University, USA \\ ${ }^{2}$ University of South Carolina, USA
}

*Corresponding author: Pamela Emanuelson, Department of Sociology, North Dakota State University, USA.

Received Date: July 09, 2019

Published Date: July 19, 2019

\begin{abstract}
In this paper we suggest that models drawn from sociological theory, much of it experimentally tested, can be useful for inferring the social structures of prehistoric and historic chiefdoms as well as activity within and change across structure.
\end{abstract}

Keywords: Experiments; Theory; Social Structure

\section{Opinion}

In this paper we suggest that models drawn from sociological theory, much of it experimentally tested, can be useful tools for inferring the social structures of prehistoric and historic chiefdoms and the social changes across the structures they take. In developing and presenting those models we recognize that there is no direct evidence for the social relations within which the people of prehistoric societies acted or for how those relations were composed into structures [1]. Nor can there be for social relations and structures are not composed of objects but of acts and, while objects degrade at various rates, acts can be observed only as they are occurring. As explained by Haas, archaeologists "can make no direct observations of people's behavior; we cannot talk to them or ask them insightful questions; we cannot listen in on their conversations. Our informants are all dead, and we can only pick up what they left behind and observe when and where they left it" [2].

Whereas the social structures of prehistoric societies cannot now be observed, the large social structures of contemporary society cannot be directly observed. They cannot because a social structure is not a single thing, but a structured assemblage of events, only the parts of which are ever observable. To grasp that structure, observations of its parts must be assembled into a structured whole and that assembly can only be done through a theory of social structure. As Wright pointed out, "even if we could obtain the archaeological record needed, we would still lack the theoretical structures essential to talking about the complex social, symbolic, and material transformations that seem to have been important in the origins of states" [3]. We hope, in this paper, to show that those theoretical structures are now at hand.

In fact, archaeologists face two problems, one unique in its difficulty and the other shared with all other social sciences. On the one hand, unlike all other social sciences, in the absence of written records, archaeology has no direct evidence whatsoever of the social relations and social structures it seeks to understand. Of course, the information on social relations and structures that is available to other social sciences is far from complete. Only a small portion of past events are ever recorded. And even today the powerful make it a point to limit what we can observe. That is to say, we know much about the poor and middle class, but very little about the elites of contemporary societies precisely because they have the power to exclude outside observers. Nevertheless, having no direct evidence at all pre-historic social acts, it would seem that archaeologists have a particularly difficult starting point for assembling an understanding of prehistoric social structures.

Why the concern with social structures? Why not be satisfied with the product of refined field methods, what Flannery Kent \& Joyce Marcus [4] called the "'high craftsmanship' of field archaeologists finding practical patterning in the real world" [5]. In fact, Flannery and Marcus did not advise stopping at the practical 
patterning given in the field but looked to social structures for prehistorical explanation. Referring to Kelly RC [6] and their own (2003) paper, they found the origin of war in the transition from unsegmented to segmented societies.

It is useful to look at the logic behind how war and social structure came to be connected. We see it as having four steps:

I. The point of departure was not observation, but the concepts "unsegmented society" and "segmented society" as given by anthropological theory.

II. The concepts "unsegmented society" and "segmented society" pointed the researchers [6,7] to the archaeological evidence identifying and differentiating prehistoric examples into the two types.

III. Archaeological evidence then empirically linked the presence of war to segmented society and the absence of war to unsegmented society.

IV. That empirical link was explained theoretically by the different organizational capabilities of the two social types - unsegmented societies cannot organize wars, whereas segmented societies can.

Much the same four-step process is found in Barfield's explanation of the rise of Asian empires [8,9]. He also began with a) the segmented - unsegmented social structural formulation, b) identified Asian tribes as segmented in contrast to those of North Africa, c) found durable and highly stratified empires where segmented tribes had been found, and d) argued that the Asian status-lineage form of segmentation led to the parallel stratified form of Asian empires.

In fact, all social sciences understand social structures only through theories for those structures. What theories are used today? Economists theorize one structure, the ideal market conceptualized today much as it was by [10] late in the 19th century. Political scientists theorize administrative structures, but their understandings are little advanced from Weber's formulations for bureaucracy now more than 100 years old [11]. And sociologists' theories of class structures are little if any advanced from Marx Karl [12] who wrote more than a century and a half ago. Some theories used by archaeologists are newer, for example, those offered by, the first two of which also used the unsegmented - segmented differentiation to good purpose [13-15]. Still, compared to dynamic sciences such as physics, chemistry and biology, social science theory seems, if not static, then slow in its development. Perhaps more to the point, the number of theoretic models for social structure that can be deployed are few and scanty.

Our argument is not to substitute a new form of explanation for the four- step process just outlined, but rather to encourage inter-disciplinary cooperation and the use of more detailed social structural models that can be deployed in future explanations also having those four - steps. Sociological models for social structures built using a theory with explicit procedures for application have better grounded properties because they have been experimentally investigated. These models offer something beyond that offered in previous prehistorical and historical explanations mentioned above. They offer the possibility of explaining social dynamics, which is to say, of explaining the transition from one social structure to another. In one such application, Emanuelson Pamela \& David Willer [16] applied models developed from two theories, Status Characteristics Theory and Elementary theory, to explain the movement through three structural forms chiefdoms are known to take.

Nevertheless, it is reasonable to ask: can experiments recently conducted shed light on social structures many of which occurred far in the past? This much should be said. Without experimentally grounded optics, the expansion of the Universe would not have been inferred from the red shift of light from distant galaxies. And without lab-based research in genetics, the evolution of modern humans, its timing and origins, might still be a mystery. Perhaps there is also a place for experimentally grounded sociological theory in the explanation of the dynamics of ancient human societies [1722].

\section{Acknowledgements}

None.

\section{Conflict of Interest}

No conflict of interest.

\section{References}

1. Childe V Gordon (1946) Archaeology and Anthropology. Southwest Journal of Anthropology 2: 243-251.

2. Haas Jonathan (1982) The Evolution of the Prehistoric State. Columbia University Press, New York.

3. Wright Henry T (1998) Uruk States in Southwestern Iran. In: Gary Feinman and Joyce Marcus (eds), Santa Fe: School of American Research Press, Pp: 173-197.

4. Flannery Kent, Joyce Marcus (2003) The Origin of War: New 14C Dates from Ancient Mexico. PNAS 100(20): 11801-1805.

5. (2012) The Death of Archaeological Theory? In: John Bintiff and Mark Pearce (eds), Oxbow Books, Pp: 23-30.

6. Kelly RC (2000) Warless Societies and the Origin of War. In: Ann Arbor (edr), The University of Michigan Press.

7. Barfield Thomas J (1989) The Perilous Frontier. MA: Blackwell Publishers, Cambridge, UK.

8. Thomas I Barfield (1990) Tribe and State Relations: The Inner Asian Perspective. In: Philip Khoury and Joseph Kostiner (eds), The University of California Press, Tribes and State Formation in the Middle East, US, Pp: 153-184.

9. Walras Léon (1874) Elements of Pure Economics or the Theory of Social Wealth, London.

10. Weber Max (1918) Economy and Society. University of California Press, US.

11. Marx Karl (1867) Capital: A Critique of Political Economy. In: Frederick Engels (ed), International Publishers, New York.

12. Sahlins Marshall D (1958) Social Stratification in Polynesia. Seattle, University of Washington Press.

13. Service Elman R (1962) Primitive Social Organization. Random House, New York. 
14. Carneiro Robert L (1970) A Theory of the Origin of the State. Science 169: 737-738.

15. Emanuelson Pamela, David Willer (2018) Social Structures in Transition: Applications of Two Theories to Chiefdoms. SOCIOUS: Sociological Research for a Dynamic World.

16. Berlin Isaiah (1961) The Concept of Scientific History. History and Theory 1: 1-31.

17. (2007) The Taking and Displaying of Human Body Parts as Trophies by Amerindians. In: Chacon Richard J, David Dye (eds), Springer Press, New York
18. Ford James (1952) Measurements of Some Prehistoric Design Developments in the Southeast.

19. Anthropological Papers of the American Museum of Natural History. 44: 309-384.

20. Hansen Mogens Herman (2006) Polis. Oxford University Press.

21. Marcus Joyce (2008) The Archaeological Evidence for Social Evolution. Annual Review of Anthropology 37: 251-66.

22. (1985) A Century of Controversy: Ethnological Issues from 1860 to 1960. Academic Press, New York. 